\title{
Micromorphology of the Early Iron Age semi-cemented floors: El Calvari del Molar (Tarragona, NE Spain) as case study
}

\section{Marta Mateu1, M. Mercè Bergadà ${ }^{2}$, Xosé-Lois Armada $^{3}$, Núria Rafel ${ }^{4}$}

1) GRAP (Grup de Recerca en Arqueologia Protohistòrica). Dept. Història i Arqueologia. Universitat de Barcelona. (Catalonia, Spain). martamateu@ub.edu

2) SERP. Dept. Història i Arqueologia. Universitat de Barcelona (Catalonia, Spain). bergada@ub.edu

3) Institute of Heritage Sciences (Incipit), Spanish National Research Council (CSIC). Santiago de Compostela (Spain). xose-lois.armada@incipit.csic.es

4) Deptartament Història. Universitat de Lleida (Catalonia, Spain).nrafel@historia.udl.cat

\section{ABSTRACT}

This paper presents the microstratigraphic analysis of the protohistoric site El Calvari del Molar, dated to the $7^{\text {th }}$ century and the first quarter of $6^{\text {th }}$ century BC. It focuses specifically on Room 8, located in the northern part.

The sedimentary record covers different stratigraphic units, including several floors with their layers of preparation and domestic structures. The study of these floors, mainly through micromorphology, allows us to determine the composition, the processing and the technical treatment as well as the possible origin of the lithological materials used in their manufacture.

We highlight that the floors are composed of earth construction, made of local carbonated materials, mainly clayey fine sands. Mixing this material with water would cause a precipitation of $\mathrm{CaCO}_{3}$ favoured by the impermeability of their preparation layers, mostly silty clay aggregates, leading to the semi-cementation of the floor, which appears to have been the aim of the builders of El Calvari. This type of earth floor brings together a series of characteristics at the construction level such as cohesion among particles and tenacity, similar features to lime mortars.

In short, we have the opinion that the micromorphological analysis is an essential tool for the study of domestic architectural elements and that its use, in our case, has allowed us 
to identify and characterize the techniques and construction strategies of this type of floor by these first protohistoric builders of the NE Iberia.

\section{KEY WORDS}

Semi-cemented floors, Earth construction, Micromorphology, El Calvari del Molar, Early Iron Age

\section{Introduction}

The geoarchaeological study of occupation surfaces and the search for floors at archaeological sites is becoming an increasingly common practice, especially in settlements, and there are different methodological approaches to help improve their interpretation. One of them is micromorphology, of which examples from as early as the 1990s provide us with detailed information on site formation processes (e.g. how floors were made and used). In the different handbooks and syntheses of Geoarchaeology and Soil Micromorphology we find sections referring to building materials, in which reference is made to the floor and usage levels of the sites or to certain indications of floors, like Goldberg and Macphail (2006), Macphail and Goldberg (2010, 2018), Milek (2014), Friesem et al. (2017) or Rentzel et al. (2017).

Courty, Goldberg and Macphail (1989) publicized the technique of applying micromorphology to the study of the architectural elements of a site made of earth-based materials, such as floors and occupation surfaces. Along the same lines, there are microstratigraphic studies related to the analysis of the different techniques and construction procedures with earth-based materials, especially in floors and occupational deposits: e.g. Khirokitia (Cyprus) (Hourani, 2003), different sites of the later Neolithic in southern France (Wattez, 2003, 2009), the Bronze Age site of Mitrou (Greece) (Karkanas and Van de Moortel, 2014), Lattes (France) (Cammas, 1994, 1999, 2003) or Tell esSafi/Gath (Israel) (Namdar et al., 2011). Also worthy of mention are several contributions that applied micromorphology to the study of occupation surfaces, floors and the use of soil at different sites (anthropic activities carried out on them) (Gé et al., 1993; Matthews, 1995, 2012; Matthews et al., 1994, 1997, 2006; Macphail et al., 1997; Shahack-Gross et al., 2005). There have also been noteworthy ethnoarchaeological and experimental studies carried out on the main floor formation processes and the use of these (e.g. Milek, 2012 or Banerjea et al., 2015). Within this framework we also find projects aimed at 
identifying and determining the use of plaster to make the floors, as in the case of the studies by Macphail and Crowter (2007), Karkanas (2007), Karkanas and Efstratiou (2009), Regev et al. (2010), Mentzer and Quade (2013) or Stoops et al. (2017).

At this point we want to specify that, according to Gé et al. (1993) and Macphail and Goldberg (2010 and 2018), we will use the term "floor" to refer to soil made with earthen material (the constructed feature), and the term "occupation surface" to refer to the living surface developed on unconstructed or constructed floor that results from the use of the floor.

Studies of floors and occupation surfaces in protohistoric sites in the Iberian Peninsula, and specifically in the northeast, are very rare and unevenly distributed. In general, the few studies carried out have been developed in field surveys (macro). These studies usually only revealed the use of earth, commonly stacked, as an occupation surfaces (Belarte, 2002; Mateu, 2016). Another type of floor has been documented only in some sites, such as in San Cristóbal (Mazaleón, Teruel) where a floor made with adobe (Fatás and Catalán, 2005) has been located.

This way we aimed to contribute to the limited existing knowledge of technological practises in protohistoric societies in NE Iberia. In this paper we analysed the phases of occupation of El Calvari site in detail, in order to be able to study its formation, the materials and technology used and ultimately the microstratigraphic sequence of the record with greater resolution. We especially focussed on the floors and on how the predominantly limestone materials were used and worked.

\section{Geographical, geological and archaeological context}

\subsection{Geographical location and geological context}

The site is in the municipal area of El Molar (Priorat, Tarragona) (Fig.1), on the summit of a small, elongated NE-SW-orientated hill $230 \mathrm{~m}$ amsl. It has gentle slopes around its perimeter, with the exception of the much steeper north-western face. It is worth mentioning that its location is less than $6 \mathrm{~km}$ in a straight line to the River Ebro, the main Phoenician trading artery in NE Iberia (Garcia i Rubert and Gracia, 2011), a strategic feature of its setting. 
Geologically, the site is on a slightly pronounced, asymmetric crest facing SW to NE, coinciding with the same orientation in the Catalan Coastal Ranges. The basement is composed of sloping massive limestone from the Middle Triassic (Muschelkalk). In the eastern sector of the settlement there is a fault contact between Triassic limestones and detrital and lutitic materials (sandstones, microconglomerates, clays and red marl) from the Early Triassic (Bundsandstein) (Fig. 2) (Carulla, 2008). The limestones are fractured and slightly karstified, thus forming a rainwater storage and discharge area that in the $\mathrm{W}$ sector in contact with the red clay of the Upper Triassic (Keuper), would favour the appearance of water sources, providing an availability of water resources for the people in El Calvari.

This hill is in the Molar-Bellmunt-Falset mining area (Tarragona province), where lead minerals were mined from the $7^{\text {th }}$ century BC until just a few decades ago, although at different intervals and with varying levels of intensity. This area, in which there are also indications of prehistoric copper mining, makes up the southern sector of a more extensive mining zone, the Priorat, which has been intensively studied since 2001 in various research projects. The results obtained show the existence of a low-level, dispersed habitat in the Late Bronze Age. In its final stages, there was a concentration of population that led to the emergence of two main settlements, El Calvari del Molar and Puig Roig (El Masroig, Priorat) (Armada et al., 2013; Rafel et al., in press). They have been linked to the exploitation of the local lead resources and lead isotope analyses have shown that this mineral was channelled towards the south-west of the Iberian Peninsula (the Tartessian area) to use in the cupellation of silver-bearing minerals (Rafel et al., 2014; Murillo-Barroso et al., 2016).

\subsection{Archaeological record}

The Calvari del Molar complex consists of a settlement and a necropolis (Fig. 3). The settlement is on the highest part of the hill, while the necropolis is about 100 metres to the south-west and some 15 metres lower. The latter site was excavated in 1930 by Salvador Vilaseca, who also opened a small trench in the settlement (Vilaseca, 1943). The excavation of the settlement was restarted in 2001 and continued until 2012, under the direction of two of the authors (N.R. and X-L.A.). 
The main occupation phase of the settlement is dated to the $7^{\text {th }}$ century and the first quarter of the $6^{\text {th }}$ century $\mathrm{BC}$, although its earliest levels are probably contemporary to the origin of the necropolis, in the final decades of the $9^{\text {th }}$ century BC or slightly later. In the most extensively excavated part, the urban layout was organised around a large, longitudinallyorientated blind wall to which the rooms were annexed (Fig. 4). This arrangement defined two sectors. In the northern sector the dwellings are orientated parallel to the wall, while in the southern one the longest axis is perpendicular to that wall (Rafel et al., 2008). In this sector, in addition to a clearly defined double defensive wall enclosing the settlement, is Room 8, whose floors are studied in this paper. This sector also has the most complex stratigraphy and the longest chronological sequence, as we describe below. In contrast, in the sector situated to the south of the wall, we have identified a single phase of occupation except for some walls at the south-western end of this area that are from a minor late reoccupation $\left(3^{\text {rd }}-2^{\text {nd }}\right.$ centuries BC).

Room 8 is a two-storey house whose general structure lasts from the first documented implementation of the settlement to the final abandonment of it. It has been possible to identify three broad occupation phases in it, some of which are in good condition. It is especially noteworthy the conservation of elements of the house furniture built on earth, something that is not usual in the geographical area where it is located. This room, which is located on a slope, has provided a cumulative archaeological sedimentation sequence of the site from the foundational moment until its abandonment in the $6^{\text {th }}$ century BC. The room has a rectangular perimeter and measures more than five metres from east to west and three metres from north to south (approximately $16 \mathrm{~m}^{2}$ in total). The room is enclosed by stone walls on all four sides, meaning that access to it in the more recent phases would have been at a higher level than that preserved today. In the earliest phases, however, the room had an entrance in its northern wall, which was subsequently blocked up. This modification is perceptible on the exterior face of that wall (SU 204), the interior face of which was cladded with earth after the original entrance had been blocked up. The area also has an earth-based domestic structure in the shape of a bench (SU 263), $40 \mathrm{~cm}$ wide with a thickness of $16 \mathrm{~cm}$, which forms the top part of the sequence on the north-eastern and southern sides studied in the paper.

The area occupied by the house makes it unnecessary to install supports for the roof. The studies carried out on the protohistoric constructions of the northeast peninsular indicate 
that this was a resource used only in constructions more than $3 \mathrm{~m}$ wide, because the wood used for the beams commonly had this maximum length. The hypothesis that it was a dwelling of two floors is supported by the presence of a central hole that is maintained throughout the life of the house, as well as the fact that in its last phases the conserved part has no opening to the outside. It should be noted that the existence of two-storey constructions in the geographical and chronological horizon in which we operate is not an exceptional fact. The documented constructed floors are exceptional in their context, since the most frequent thing in the comparable settlements is the implantation of simply stacked earth floors.

The room presents a long stratigraphic sequence in which we have evidenced three periods. The oldest episode, phase 1 , is formed by silty sands with gravels and constitutes the floor layer preparation (SU 333) that contains material from the late- $9^{\text {th }}$ and $8^{\text {th }}$ centuries BC. Above it the first floor appears, consisting of silty clayey fine sands (SU 317). Next, the second phase is another thicker floor layer preparation (SU 316) formed by silty clay aggregates located with a floor (SU 296/309) also composed of silty clayey fine sands. The last episode, phase 3, is composed of SU 287, the thickest floor layer preparation made of aggregates of clayey sands and silty clays and finally, the domestic element, the bench (SU 263), composed of silty clays, crowns the sequence. Phase 2 and 3 are characterised by the absence of wheel-thrown pottery and present a chronology from c. 800 to $650 \mathrm{BC}$.

In Table I we give the detailed field sedimentary description of the stratigraphic units distinguished archaeologically and included in this study.

\section{Methods}

The methodology used to analyse the floors of the different phases of occupation of the site consisted mainly of soil micromorphology of the sedimentary profiles conserved in the settlement, attached to the NE and S walls of the object of study (Fig. 5). They are around $50 \mathrm{~cm}$ thick and are located at the base of the bench. The lithological materials of the substrate of the Muschelkalk (Sample A) and the transition to the Bundsandstein (Sample B) were also analysed to compare their possible relationship with the constructed material (Fig. 6). Some scattered fragments of such floors and their preparations 
corresponding to SU 302 and SU 269 are located in the N-NW and SE of the same Room 8 (Bergadà and Mateu, 2011).

For the collection of both the archaeological and the geological samples ( 6 in total) we followed the protocol used and explained by Bergadà (1998): this consisted of placing the sediment into boxes lined with plaster, enabling us to obtain blocks without altering the structure and the position of the sedimentary filling. Once the sediment blocks had been described macroscopically (Mateu et al., 2013; Mateu, 2016), we proceeded with the thin section preparation. The samples were consolidated by impregnating them with a polystyrene resin. After this process, a $25 \mu \mathrm{m}$ thin section measuring $13.5 \mathrm{x} 5.5 \mathrm{~cm}$ was produced (Benyarku and Stoops, 2005). For each sediment block taken in the field, one thin section was obtained (Fig. 7).

The sections were examined using a petrographic microscope $(25 \mathrm{x}$ to $400 \mathrm{x}$ magnification), under plane polarized (PPL), crossed polarized (XPL) and oblique incident light (OIL). The descriptions followed published guidelines (Bullock et al., 1985; Courty et al., 1989; Bergadà, 1998; Stoops, 2003).

According to the descriptions we have created different Microfacies Types (MFTs) (Goldberg and Macphail, 2006) that correspond to the SUs distinguished in the field. In these MFT one of the main objectives was to establish whether the materials that formed them were natural or anthropogenic. To identify these last cases we find some characteristic features that also help us determine that we are dealing with earth-based materials. Thanks to these characteristics we also know how they were developed and, depending on the case, their use. A massive microstructure is an example of these features; with some vesicles or vugh voids that come either from its modelling or processing (water or air trapped in the groundmass in its preparation), or moldic voids (occasionally with the presence of phytoliths). Dusty clay infillings that are sometimes rich in iron oxides and hydroxides are another feature. Finally, a main feature is the accurate selection of both the coarse fraction (mineral and anthropogenic) and the micromass to make these materials (Mateu, 2016; Gé et al., 1993; Cammas, 1994, 2003; Duvernay, 2003; Wattez, 2003; Germain-Vallée et al., 2011).

The micromorphological analysis was completed with scanning electron microscopy (ESEM-EDX) in back-scattered electron (BSE) mode and microprobe analyses on thin 
sections and in the specific case of the floors, level preparations and geological samples. $\mathrm{XRD}$ analyses were made to characterise the materials used in the floor. These analyses were carried out by the Scientific and Technological Centre at the University of Barcelona (CCiT-UB).

\section{Results}

We were able to determine seven Microfacies Types (MFTs) (Goldberg and Macphail, 2006) that correspond to the SUs distinguished in the field, which we have described in more detail in Table II. We were able to group the MFTs according to the description of their composition and we have classified them as follows: MFTs that form part of the occupation surfaces (floor and preparation layers) and MFTs that make up other earth construction elements, such as the bench.

This section is divided into four to explain the results obtained: floors, layer preparations, domestic structures (bench) and supply of lithological resources.

One of the pedofeatures common to all the MFTs is the biological activity of the soil organisms, which is manifested mainly by the presence of chambers, channels, phytomorphic calcite infillings and earthworm biospheroids.

\subsection{Floors (MFT2 and MFT6)}

These layers are greyish-yellow in colour and composed of a silty clayey fine-sand groundmass (Fig. 8). We only found some voids - moldic- (Fig. 8c), which were interpreted as resulting from the possible plant components due to their shape or content, some with articulated phytoliths that support the idea of in-situ decomposed plant remains (Fig. 9) (Vrydaghs et al., 2017); and other vughy and round vesicle voids characteristic of the mixing and preparation of the floor (Fig. 8d) (Cammas, 2003; Wattez, 2003). Nevertheless, in general they had a poorly developed porosity. In this groundmass we observed infillings and dusty clay hypo/coatings in microaggregates and in sands particles, above all in MFT 6 (which is thicker).

On the uppermost of MFT 6 (9 $\mathrm{cm}$ thick) we found very small bone and charcoal fragments that correspond to a possible use of the floor (Fig. 10), although we do not have enough evidence to be able to determine this clearly. The mineralogy of such floors is 
composed of calcite, quartz, clay (type illite / muscovite and chlorite), dolomite and feldspars, data complemented by the XRD analysis (Fig.11).

\subsection{Floors layers preparation (MFT1, MFT3, MFT4 and MFT5)}

Regarding the layers of preparation appear two different types: detrital sedimentary accumulation (MFT 1-SU 333) and aggregates of reddish earth building elements (MFT 5-SU 287- and MFT4-MFT 3 -SU 316).

\subsubsection{Detritic sedimentary accumulation}

MFT1 (SU 333) is made of a mixture of components and detritic material (Fig. 12, a -b) in which the coarse fraction dominates, with stones, gravels, sandy particles and anthropogenic remains (like some charcoal, bone and flint fragments). These have a random distribution and a higher porosity than the rest of the sequence and a granular microstructure. This MFT represents the oldest type of preparation analysed.

\subsubsection{Aggregates of reddish earth building elements (MFT 3-SU 316, MFT4 and MFT} 5-SU 287)

They are characterized by aggregates composed mainly of reddish silty clays with fine sands and some gravels (Fig. 12, c-f). The microstructure of these aggregates is massive with moldic voids, and in some cases can be distinguished as phytoliths or charred residues. Some of these aggregates appear to have combustion traces: the detrital material, mainly limestone, has fissures with traces of dissolution and impregnations of iron oxides and hydroxides. A crack-type microstructure is created by the drying out of the clay (Macphail and Goldberg, 2010). Partially burned plant remains were also found. Prismatic-type calcitic pseudomorphs appear in the cracks of the aggregates (Fig. 13) in SU 302 of this same area (Bergadà and Mateu, 2011), also corresponding to this type of microfacies,

We would also add MFT4 to this category, composed of aggregates of reddish earth building elements as well as silty clayey fine sands.

\subsection{Domestic structure}


MFT 7 is clearly linked to the bench (SU 263) excavated next to the northeastern and southern walls of the area. Very clayey material (mainly illite) was used to build this bench, apparently without combustion traces. It has a massive microstructure with no evidence of plant remains or minerals used as a temper, and no coarse fraction (Fig. 14). This bench, unlike other construction elements, does not appear shaped.

\subsection{Supply of lithological resources}

Sample A is a partially dolomitized sparry limestone and corresponds to a carbonate rock of the Muschelkalk. Sample B corresponds to a rock from the transition between the facies of the Bundsandstein and Muschelkalk, which is predominantly carbonated and mostly micritic, although there are areas with carbonate crystals that exceed $50-100 \mu \mathrm{m}$, with varying proportions of clay and iron oxides giving this component a reddish tone to the rock.

In the archaeological samples, the floors themselves and the materials related to their preparation have a composition correlated to the rocks mentioned above, as observed in the microanalysis of the thin sections (Fig. 15 and Fig. 16).

The preparation materials have higher proportions of clays with iron oxides. In the floors, the abundant inclusion of fine, mainly quartz sands is observed, a fact reflected also in the XRD analysis. The geology of the most immediate surroundings do not contain these siliceous components, which suggests that the floors could also contain particles from other areas, for example conglomerates and silty sands from the Paleogene or Quaternary fillings (See Fig. 2).

\section{Discussion}

\subsection{Floors}

Constructed floors MFT2 (SU 317) and MFT 6 (SU 278) are characterised by earth-based materials made up of silty clayey fine sands together with remains of plant components (phytoliths and moldic voids). The groundmass comes mainly from the carbonate materials of the site. Supplies were obtained from nearby locations for reasons of effectiveness and efficiency, as recorded in the majority of studies (Norton, 1986; Houben and Guillaud, 1994; Belarte, 2002). 
Its preparation is that typical of working with earth-based construction materials (Mateu, 2016). Firstly, the detritic material (more sandy) was mixed with the rest of the components (plant remains, gravel or pebbles, and water), and then well puddled in order to mould and prepare the different elements (Gé et al., 1993; Cammas, 1994, 2003; Duvernay, 2003; Wattez, 2003; Germain-Vallée et al., 2011; Mateu, 2016). Once puddled, the mixture would have been applied, which we have only been able to document well in the floors, especially in the most recent (MFT 6). This is the technique known as direct shaping (Houben and Guillaud, 1994; Belarte, 2002; Mateu, 2016; Friesem et al., 2017). It consists of applying layers that are smoothed flat to cover the whole surface of the area until the desired thickness and density is achieved. In the analysed floors the microstructure is massive, with vughs and vesicles caused by the air and water trapped in them when they were laid. We also observed the inclusion of water in the infillings of fine material following the horizontal layers of the groundmass.

The composition of these floors is characterized by an increase of the sand fraction compared to the preparation layer, and an inclusion of few plant components. While the sand fraction already fulfils the function of plant components: their inclusion could have resulted in an increased resistance to traction and the avoidance of fracturing (CRAterre, 1983; Duvernay, 2003).

As we have previously mentioned, mixing this material with water caused a precipitation of $\mathrm{CaCO}_{3}$ leading to the semi-cementation of the floor, the objective of the builders of El Calvari. This carbonation would be favoured by the fact that the lower layer of preparation is impermeable and would not facilitate drainage, since the materials are mainly made of silty clay aggregates which would make cementing easier.

This type of floor provides a series of advantages from the constructive point of view. It offers considerable cohesion and tenacity, accentuated by the inclusion of quartz particles in the sandy fraction that give hardness to the material. It also provides an impermeability, although it is breathable - lets moisture pass, without the need to use lime and finally, it requires less maintenance of the constructed floor.

Semi-cemented floors such as those located in The Calvari have been documented in other archaeological sites from the Early Iron Age, as in Sant Jaume (Alcanar, Montsià, Tarragona) with the use of a dolomitic groundmass (Mateu, 2016). As in other 
archaeological records such as Uppåkra (Scania, Sweden) also from the Iron Age, or in Wheat Barn, Cressing Temple (Essex, UK) in the $12^{\text {th }}$ century (Macphail and Goldberg, 2010, 2018). In short, we believe that this type of semi-cemented material, mostly in floors, has a series of similar construction characteristics to lime mortars.

The use of lime in this geographical area has been located in a generalized way since the $6^{\text {th }}$ century BC, for example, lime kilns are located in the Alorda Park site (Calafell, Tarragona) and their use can be visually documented in building elements such as floors, coatings and plasters (Sanmartí and Santacana, 1992; Belarte, 2001); however there is little data on its use in settlements prior to the Iberian period (Belarte, 2001).

There is a certainty that in Iberia the use of lime as a constructive material was introduced by the influence of the Eastern Mediterranean (Rouillard et al., 2007) during the Late Prehistory and the Protohistory, possibly from Late Bronze Age but especially during The Iberian period. Its use has already been confirmed archaeologically in Phoenician sites (Ferrer, 2010), as in the Fonteta record (Guardamar, Alicante) (Belarte and Gailledrat, 2003; Rouillard et al., 2007).

Recently in the Mediterranean basin of Iberia, its use in earth construction elements has been identified in the mixture in different settlements from the Neolithic to the Bronze Age such as Torreta-el Monastil (Elda, Alicante) or Cabezo Pardo (San Isidro/Granja de Rocamora, Alicante) (Martínez and Vilaplana, 2010; Jover et al., 2016).

From the data available in the absence of generalized geochemical and micromorphological studies, it is difficult to analyse the introduction and use of lime as a construction material and its specific use in floors. However, according to Houben and Guillaud, (1994), Chazelles, (1997), Belarte, (2001) and Mateu (2016), we believe that the procedure for the construction materials is based on the type of building element required as well as the raw material that available in the immediate surroundings.

One of the micromorphological contributions to the study of floors is the differentiation of those micro-facies that in the majority of cases we are unable observe macroscopically: the passive, reactive and active zone (Ge et al., 1993; Cammas, 1994; 1999; Matthews et al., 1994; Macphail and Goldberg, 2018). 
In our case, these floors correspond to the passive zone, since no anthropogenic components of domestic activities are found; most likely, due to the sweeping or lowering as a system for a new construction of the next floor. There are no changes caused by effects of trampling since they are made with very resistant materials (Gé et al., 1993). According to Macphail and Goldberg (2010), floors without remains are the result of frequent sweeping with the waste being dumped elsewhere, which reflects busy floors with a certain intensity. In contrast, the most recent floor, MFT 6, with a greater sedimentary thickness, contains some domestic refuse corresponding to the "active zone", as it was probably the last floor laid in the site and also the bench is located above it, which may have been why sweeping was not necessary.

\subsection{Floor layer preparation}

As we have expressed in the results, we located two types of floor preparation that would represent the "passive zone" and that appear well registered in the site. The first, named Detrital sedimentary accumulation MFT 1 (SU 333), is the earliest phase and distinguishable by its composition of detritic material, which is different to that of the other MFTs. Its components present a chaotic organisation with a wide range of sizes of charcoal, bone, flint, etc. fragments; characteristics that lead us to believe that it could have been a dump (Miller et al., 2009). This would correspond to a layer of preparation or levelling of the land; perhaps, because the bedrock outcrops at a shallow depth on the surface of the soil.

The second type called Aggregates of reddish earth building elements is located in the intermediate and upper episodes, such as MFT 3 and MFT 5 (SUs 316 and 287), as well as some aggregates from MFT 4. They are made of a mixture of earth construction material aggregates that are characterised by their generally reddish colour probably from diverse items of domestic architecture that were used in a levelling phase when the area was rebuilt (for example in Cammas, 1994, 1999; Mathews et al., 1997; Shahack-Gross et al., 2005 or Friesem et al., 2014). Some of these aggregates appear with important traces of combustion, possibly coming from domestic structures of hearths or ovens, as is the case of the fragment corresponding to the SU 302 which still has remains of ashes (calcium carbonate pseudomorphs of prismatic crystals) conserved in its fissures of bark of woody materials (Brochier, 1996; Canti and Brochier, 2017). In some of these, there are abundant aggregates, with remains of plant origin as a temper that probably helped to 
stabilise the mixture with the aim of preventing fissures when it dried (CRAterre, 1983; Duvernay, 2003). In the MFT4 preparation we have also been able to distinguish fragments of aggregates coming from the floor, their origin is probably due to a lowering process developed by builders.

\section{Conclusions}

From the analysis carried out, we believe that micromorphology is essential for the characterization of construction techniques and the recognition of domestic activity associated with occupation surfaces and especially constructed floors.

In the case of the El Calvari del Molar, dated from the $7^{\text {th }}$ century to the first quarter of the $6^{\text {th }}$ century, it has allowed us to analyse in detail the type of materials used, the construction system and the evidence of the occupations. The raw materials exploited for these constructions were mainly the lithological resources of the surrounding environment - the bedrock of the site. Three episodes of occupation have been identified and in all of them there are two constructive units: floors and floor layer preparations.

The floors always comprise carbonated constructed earth, mainly clayey fine sands, formed by direct modeling, with the semi-cementation of the floor obtained as a final result.

This type of floor offers a series of advantages. It has great particle adhesion and resistance that is also reinforced by the inclusion of quartz particles in the sand fraction, giving more consistency and stability to the construction material and requiring less maintenance of the floor. No domestic refuse appears on their surfaces, possibly due to frequent sweeping, which would indicate occupations with certain intensity; except for the most recent where the sweeping was not so necessary since the domestic element of the bench was positioned above it.

Preparation layers composed of possible debris of diverse architectonic elements, silty clay aggregates, and / or of reductions of the same floors are present, where the objective appears to have been to level and thus to modify the room. The only exception is the oldest preparation, which is made with dumped detrital sedimentation. From these preparations we highlight the fact that the majority of their composition is clayey, which from the constructive point of view favours poor drainage as they are impermeable and 
further facilitates the cementation of the floor. These preparations also reflect the existence of different moments of significant remodelling of this area of the settlement.

In short, we believe that the semi-cemented floors and specifically those in El Calvari del Molar represent a technical and constructive solution without the use of lime mortar, obtaining results with similar qualities and properties; this fact that makes us think that they can be located as long as their builders have the necessary raw materials beyond the geographical and chronocultural scope at their disposal.

\section{Acknowledgments}

We would like to thank Dr. M. Àngels Canals of the Department of Mineralogy, Petrology and Applied Geology at the University of Barcelona for her contribution in the description and interpretation of the geological samples and for her comments and suggestions and also Dr. Richard I. Macphail of the University College London for his first comments and suggestions on the soil micromorphology analysis. Thoughtful reviews by anonymous referees are gratefully acknowledged.

M.M. is especially grateful to Sonia Carbonell Pastor and the second team of the 2017 excavation campaign at the Sant Jaume archaeological site.

This paper is part of the HUM2004-04861-C03-01 and HUM2007-65725-C03 research projects funded by the Ministry of Science and Innovation and the HAR2010-1105-C02 research project funded by the Ministry of Economy and Competitiveness. The research has also been funded by the grants awarded to the "El jaciment protohistòric del Calvari del Molar i l'àrea minerometal·lúrgica Molar-Bellmunt-Falset" research programme by the Culture Department of the Regional Government of Catalonia, the Tarragona Provincial Government and the municipality of El Molar (in order to carry out the excavation of the El Calvari archaeological site).

\section{References}

Armada, X.-L., Rafel, N., Graells, R., Roqué, R., 2013. Orígenes del urbanismo y dinámicas sociales en el Bronce Final de Cataluña meridional: El Avenc del Primo (Bellmunt del Priorat, Tarragona). Trabajos de Prehistoria. 70 (2), 278-294. 
Banerjea, R.Y., Bell, M., Matthews, W., Brown, A., 2015. Applications of micromorphology to understanding activity areas and site formation processes in experimental hut floors. Archaeological and Anthropological Sciences. 7 (1), 89-112.

Belarte, M.C., 2001. Les tècniques constructives al món ibèric, in M.C. Belarte, J. Pou, J. Sanmartí and J. Santacana (Eds.). Tècniques constructives d'època ibèrica i experimentació arquitectònica a la Mediterrània. Actes de la I Reunió Internacional d'Arqueologia de Calafell, Arqueomediterrània. 6, 27-41.

Belarte, M.C., 2002. La construcció amb terra a la protohistòria. Societat Catalana d'arqueologia, Barcelona.

Belarte, M.C., Gailledrat, É., 2003. Murs protohistoriques de terre massive sur la côte orientale de la péninsule ibérique (VIIe-IIIe s. av. J.-C.): l'exemple de Guardamar del Segura (prov. d'Alicante), in: Chazelles, C.A. de, Klein, A. (Eds.), Terre modelée, decoupée ou coffrée. Matériaux et modes de mise en oeuvre. Échanges transdisciplinaires sur les constructions en terre crue. Actes de la table-ronde de Montpellier (17-18 novembre 2001), pp. 283-297.

Benyarku, C.A., Stoops, G., 2005. Guidelines for Preparation of Rock and Soil Thin Sections and Polished Sections. Department of Environment and Soil Science, University of Lleida, Lleida.

Bergadà, M.M., 1998. Estudio geoarqueológico de los asentamientos prehistóricos del Pleistoceno Superior y el Holoceno inicial en Catalunya. BAR International Series 742. Archeopress, Oxford.

Bergadà, M.M., Mateu, M. 2011. Informe micromorfològic del jaciment El Calvari (EL Molar, Priorat): UEs 278, 302 i 269. Report SERP-Departament de Prehistòria, Història Antiga i Arqueologia, Universitat de Barcelona (unpublished).

Brochier, J.E., 1996. Feullies ou fumiers? Observations sur le rôle des opusieres sphérolitiques dans l'interprétation des dépôts archéologiques holocènes. Anthropozoologica. 24, 19-30. 
Bullock, P., Fedoroff, N., Jongerius, A., Stoops, G., Tursina, T., 1985. Handbook for Soil Thin Section description. Waine Reserach Publications, Wolverhampton.

Cammas, C., 1994. Approche micromorphologique de la stratigraphie urbaine à Lattes: premiers résultats. Lattara: Mélanges D’histoire et D'archéologie de Lattes.7, 181-202.

Cammas, C., 1999. Dynamique pédo-sédimentaire urbaine. Modes de construction et d'ocupation à Lattes au IVe s.av.n.è. Lattara: Mélanges D'histoire et D'archéologie de Lattes. 12, 211-227.

Cammas, C., 2003. L'architecture en terre crue à l'Âge du fer et à l'époque romaine: apports de la discrimination micromorphologique des modes de mise en oeuvre, in: Chazelles, C.A. de, Klein, A. (Eds.), Terre modelée, decoupée ou coffrée. Matériaux et modes de mise en oeuvre. Échanges transdisciplinaires sur les constructions en terre crue. Actes de la table-ronde de Montpellier (17-18 novembre 2001), pp. 33-53.

Canti, M.G., Brochier, J.E., 2017. Plant ash, in: Nicosia, C., Stoops, G. (Eds.), Archaeological Soil and Sediment Micromorphology. NJ: Wiley, Hoboken, pp. 147-154.

Carulla, N., 2008. Caracterització geomorfològica del jaciment del Calvari del Molar (El Priorat). Estudis de geologia aplicada, anàlisis i evolució del territori, Altafulla, Tarragona (Unpublished).

Chazelles, C.A. de, 1997. Les maisons en terre de la Gaule méridionale. Monographies instrumentum 2. Éditions Monique Mergoil, Montagnac.

Courty, M.A., Goldberg, P., Macphail, R.I., 1989. Soils and Micromorphology in Archaeology. Cambridge University Press, Cambridge.

CRAterre, 1983. Construire en terre. Editions A, Paris.

Duvernay, T., 2003. La construction en terre crue: potentiel des restes en position secondaire. Le cas d'un site rural du Bassin parisien (opérations d'archéolgie préventive de Ville-Saint-Jacques/Varennes-sur-Seine/Seine-et-Marne,77), in: Chazelles, C.A. de, Klein, A. (Eds.), Terre modelée, decoupée ou coffrée. Matériaux et modes de mise en oeuvre. Échanges transdisciplinaires sur les constructions en terre crue. Actes de la tableronde de Montpellier (17-18 novembre 2001), pp. 55-71. 
Fatás, L., Catalán, S., 2005. La construcción con tierra en la protohistoria del Bajo Aragón: El caso de San Cristóbal de Mazaleón. Saldvie. 5, 131-141.

Ferrer, C., 2010. Los adobes y la arquitectura del barro en la Bastida de les Alcusses (Moixent, Valencia). Una aproximación desde el análisis sedimentológico. Archivo de Prehistoria Levantina. XXVIII, 273-300.

Friesem, D.E., Karkanas, P., Tsartsidou, G., Shahack-Gross, R., 2014. Sedimentary processes involved in mud brick degradation in temperate environments: a micromorphological approach in an ethnoarchaeological context in northern Greece. Journal of Archaeological Science. 41, 556-567.

Friesem, D., Wattez, J., Onfray, M., 2017. Earth Construction Materials, in: Nicosia, C., Stoops, G. (Eds.), Archaeological Soil and Sediment Micromorphology. NJ: Wiley, Hoboken, pp. 99-110.

Garcia i Rubert, D., Gracia Alonso, F., 2011. Phoenician trade in the North-East of the Iberian Peninsula: A historiographical problem. Oxford Journal of Archaeology. 30 (1), 33-56.

Gé, T., Courty, M.A., Matthews, W., Wattez, J., 1993. Sedimentary formation processes of occupation surfaces, in: Goldberg, P., Nash, D.T., Petraglia, M.D. (Eds.), Formation Processes in Archaeological Context. Monographs in World Archaeology, Vol. 17. Prehistory Press, Madison, WI, pp. 149-164.

Germain-Vallée, C., Prévost-Dermarkar, S., Lespez, L., 2011. Stratégies de prélèvement et de mise en oeuvre de la "terre à bâtir" des structures de combustion néolithiques du site de Dikili Tash (grèce) à partir d'une étude micromorphologique. ArchéoSciences. 35, 4163.

Goldberg, P., Macphail, R.I., 2006. Practical and Theoretical Geoarchaeology, Blackwell, Malden, MA.

Houben, H., Guillaud, H., 1994. Earth construction: a comprehensive guide. Intermediate Technology Publications, London. 
Hourani, F., 2003. Les matériaux de construction en terre à Khirokitia (Chypre): origines, techniques de préparation et emplois, in: Chazelles, C.A. de, Klein, A. (Eds.), Terre modelée, decoupée ou coffrée. Matériaux et modes de mise en oeuvre. Échanges transdisciplinaires sur les constructions en terre crue. Actes de la table-ronde de Montpellier (17-18 novembre 2001), pp. 161-168.

Jover, F.J., Pastor, M., Martínez, I., Vilaplana, E., 2016. El uso de la cal en la construcción durante la Prehistoria recinte: nuevas aportacions para el levante de la península Ibérica, Arqueología de la Arquitectura, 13: e039. doi: http://dx.doi.org/10.3989/arq.arqt.2016.005

Karkanas, P., 2007. Identification of Lime Plaster in Prehistory Using Petrographic Methods: A Review and Reconsideration of the Data on the Basis of Experimental and Case Studies. Geoarchaeology: An International Journal. 22 (7), 775-796.

Karkanas, P., Efstratiou, N., 2009. Floor sequences in Neolithic Makri, Greece: micromophology reveals cycles of renovation. Antiquity. 83, 955-967.

Karkanas, P., Van de Moortel, A., 2014. Micromorphological analysis of sediments at the Bronze Age site of Mitrou, central Greece: patterns of floor construction and maintenance. Journal of Archaeological Science. 43, 198-213.

Macphail, R.I., Courty, M., Hather, J., Wattez, J., Ryder, M., Cameron, N., Branch, N., 1997. The soil micromorphological evidence of domestic occupation and stabling activities. Memorie dell'Istituto Italiano di Paleontologia Umana. 5, 53-88.

Macphail, R.I., Crowter, J., 2007. Soil micromorphology, chemistry and magnetic susceptibility studies at Huizui (Yiluo Region, Henan Province, northern China), with special focus on a typical Yangshao floor sequence. Indo-Pacific Prehistory Association Bulletin. 27, 103-113.

Macphail, R.I., Goldberg, P., 2010. Archaeological materials, in: Stoops, G., Marcelino, V., Mees, F. (Eds.), Interpretation of Micromorphological Features of Soils and Regoliths. Elsevier, Amsterdam, pp. 589-622. 
Macphail, R.I., Goldberg, P., 2018. Applied soils and Micromorphology in Archaeology. Cambridge Manuals in Archaeology. Cambridge University Press, Cambridge.

Martínez, I., Vilaplana, E., 2010. Dos fragmentos constructivos procedentes del yacimiento de la Torreta-El Monastil (Elda-Alicante): Análisis mediante diferentes técnicas instrumentales (FRX, DRX, FTIR-IR, TG-ATD, SEM-EDX), in: Jover, F.J. (Ed.), La Torreta-El Monastil (Elda, Alicante): del IV al III milenio AC en la cuenca del río Vinalopó. Serie Excavaciones Arqueológicas, Alicante. Memorias no5, pp. 119-137.

Mateu, M., Bergadà, M.M., Garcia i Rubert, D., 2013. Manufacturing technical differences employing raw earth at the protohistoric site of Sant Jaume (Alcanar, Tarragona, Spain): Construction and furniture elements. Quaternary International. 315, 76-86.

Mateu, M., 2016. Estudi de la terra crua durant la primera edat del ferro al nord-est de la península Ibèrica des de les perspectives micromorfològica i tipològica. Els materials del jaciment de Sant Jaume (Alcanar, Montsià). PhD thesis. Universitat de Barcelona. http://hdl.handle.net/10803/397708

Matthews, W., 1995. Micromorphological characterisationand interpretation of occupation deposits and microstratigraphic sequences at Abu Salabikh, in: Barham, T., Bates, M., Macphail, R.I. (Eds.), Archaeological Sediments and Soils, Analysis, Interpretation and Management. Archetype Books, Southern Iraq, London, pp. 41-74.

Matthews, W., 2012. Household Life Histories and Boundaries: Microstratigraphy and Micromorphology of Architectural Surfaces in Building 3 (BACH), in: Tringham, R., Stevanovic, M. (Eds.), Last House on the Hill: BACH Area Reports from Çatalhöyüc, Turkey. Monumenta Archaeology 27, pp. 205-222.

Matthews, W., Postgate, J.N., Payne, S., Charles, M.P., Dobney, K., 1994. The imprint of living in an Early Mesopotamian City: questions and answers, in: Luff, R., RowleyConwy, P. (Eds.), Whither Environmental Archaeology. Oxbow Monograph. Vol. 38. Oxbow Books, Oxford, pp. 171-212. 
Matthews, W., French, C., Lawrence, T., Cutler, D.F., Jones, M.K., 1997. Microstratigraphic and formation processes activities of site human. World Archaeology. 29 (2), 281-308.

Matthews, W., Wiles, J., Almond, M.J., 2006. Micromorphology and microanalysis of architectural surface materials and residues: investigation of source materials and the lifecycle of buildings. Çatalhöyük, Archive Report.

Mentzer, S.M., Quade, J., 2013. Compositional and isotopic analytical methods in archaeological micromorphology. Geoarchaeology: An International Journal. 28 (1), $87-$ 97.

Milek, K., 2012. Floor formation processes and the interpretation of site activity areas: An ethnoarchaeological study of turf buildings at Thverá, northeast Iceland. Journal of Anthropological Archaeology. 31, 119-137

Milek, K., 2014. Micromorphology of occupation deposits on archaeological sites, in: Bajer, A., Lisá, L. (Eds), Soil Micromorphology in General and Archaeological Context. Mendel University in Brno, Brno, pp. 60-79.

Miller, C.E., Conard, N.J., Goldberg, P., Berna, F., 2009. Dumping, sweeping and trampling: experimental micromorphological analysis of anthopogenically modified combustion feature. P@lethnologie. 2, 25-37.

Murillo-Barroso, M., Montero-Ruiz, I., Rafel, N., Hunt, M.A., Armada, X.-L., 2016. The macro-regional scale of silver production in Iberia during the first millennium $\mathrm{BC}$ in the context of Mediterranean contacts. Oxford Journal of Archaeology. 35 (1), 75-100.

Namdar, D., Zukerman, A., Maeir, A.M., Katz, J.C., Cabanes, D., Trueman, C., ShahackGross, R., Weiner, S., 2011. The 9th century BCE destruction layer at Tell es-Safi/Gath, Israel: integrating macro- and microarchaeology. Journal of Archaeological Science. 38, 3471-3482.

Norton, J., 1986. Building with Earth: a handbook. Intermediate Technology Development Group Limited. 
Rafel, N., Armada, X.-L., Belarte, C., Fairén, S., Gasull, P., Graells, R., Morell, N., Pérez, A., Villalba, P., 2008. El área minero-metalúrgica del Baix Priorat (Tarragona) en la protohistoria. Explotación y redes de intercambio. Revista d'Arqueologia de Ponent. 18, 245-269.

Rafel, N., Montero-Ruiz, I., Soriano, I., Hunt, M.A., Armada, X.-L., 2014. Nuevos datos sobre la minería pre y protohistórica en Cataluña. Cuadernos de Prehistoria y Arqueología de la Universidad de Granada. 24, 147-166.

Rafel, N., Soriano, I., Armada, X.-L., Hunt, M.A., Montero-Ruiz, I., in press. Lead and copper mining in Priorat county (Tarragona, Spain): From cooperative exchange networks to colonial trade (2600-500 BC), in: Armada, X.-L., Murillo-Barroso, M., Charlton, M. (Eds.), Metals, minds and mobility: Integrating scientific data with archaeological theory. Oxbow Books, Oxford.

Regev, L., Zukerman, A., Hitchcock, L., Maeir, A.M., Weiner, S., Boaretto, E., 2010. Iron Age hydraulic plaster from Tell es-Safi/Gath, Israel. Journal of Archaeological Science. 37 (12), 3000-3009.

Rentzel, P., Nicosia, C., Gebhardt, A., Brönnimann, D., Pümpin, C., Ismail-Meyer, K., 2017. Trampling, Poaching and the Effect of Traffic, in: Nicosia, C., Stoops, G. (Eds.), Archaeological Soil and Sediment Micromorphology. NJ: Wiley, Hoboken, pp. 281-297.

Rouillard, P., Gailledrat, É., Sala Sellés, F., 2007. L’établissement protohistorique de La Fonteta: fin VIIIe - fin VIe siècle av. J. -C. Casa de Velázquez, Madrid.

Sanmartí, J., Santacana J., 1992. El Poblat ibèric d'Alorda Park. Calafell, Baix Penedès. Campanyes 1983-1988. Generalitat de Catalunya. Departament de Cultura, Barcelona.

Shahack-Gross, R., Albert, R.M., Gilboa, A., Nagar-Hilman, O., Sharon, I., Weiner, S., 2005. Geoarchaeology in an urban context: The uses of space in a Phoenician monumental building at Tel Dor (Israel). Journal of Archaeological Science. 32, 14171431.

Stoops, G., 2003. Guidelines for analysis and description of soil and regolith thin sections. SSSA, Madison, WI. 
Stoops, G., Canti, M.G., Kapur, S., 2017. Calcareous mortars, plasters and floors, in: Nicosia, C., Stoops, G. (Eds.), Archaeological Soil and Sediment Micromorphology. NJ: Wiley, Hoboken, pp. 189-199.

Vilaseca, S., 1943. El poblado y necrópolis prehistóricos de Molá (Tarragona). Acta Arqueológica Hispánica I. Madrid.

Vrydaghs, L., Devos, Y., Pető, A., 2017. Opal Phytoliths, in: Nicosia, C., Stoops, G. (Eds.), Archaeological Soil and Sediment Micromorphology. NJ: Wiley, Hoboken, pp. 155-160.

Wattez, J., 2003. Caractérisation micromorphologique des matériaux façonnés en terre crue, dans les habitats néolithiques du sud de la France: 1'exemple des sites de JacquesCoeur (Montpellier, Hérault), du Jas-del-Biau (Millau, Aveyron), et de La Capoulière (Mauguio, Hérault), in: Chazelles, C.A. de, Klein, A. (Eds.), Terre modelée, decoupée ou coffrée. Matériaux et modes de mise en oeuvre. Échanges transdisciplinaires sur les constructions en terre crue. Actes de la table-ronde de Montpellier (17-18 novembre 2001), pp. 21-31.

Wattez, J., 2009. Enregistrement sédimentaire de l'usage de la terre crue dans les établissements néolithiques du Sud de la France: le cas des sites du Néolithique final de La Capoulière 2 et du Mas de Vignoles IV, in: Beeching, A., Sénépart, I. (Eds.), De la maison au village. L'habitat néolithique dans le Sud de la France et le Nord-Ouest méditerranéen Actes de la table ronde des 23 et 24 mai 2003 Marseille/Musée d'Histoire de la Ville de Marseille. Mémoire XLVIII. Société Préhistorique Française, pp. 199-218.

\section{Index of tables}

Table I. Sedimentary field descriptions of the profiles.

Table II. Micromorphological descriptions of MFTs.

\section{Index of figures}

Figure 1. Location of El Calvari del Molar (Tarragona) in the NE Iberia.

Figure 2. Geological location (Carulla, 2008, modified).

Figure 3. Aerial view of El Calvari del Molar. 
Figure 4. Plan of the archaeological site and detail of the Room 8 with the location of samples (M1, M2 and M3).

Figure 5. Aerial view of room 8 with the two profiles (Blue: profile 1; Green: profile 2). Front photographs of the two profiles with the process of sampling (Above: profile 1 M1 and M2; Down: profile 2 - M3).

Figure 6. Photograph of the two geological formations around the site: location Muschelkalk (Sample A) and the transition to the Bundsandstein (Sample B).

Figure 7. Photographs of the three samples before making their thin sections accompanied by indication of the different MFTs identified. Cronostratigraphic order of the site.

Figure 8. Photomicrographs of the floors MFTs (with silty clayey fine sands groundmass). a - b) MFT 2 arrow dusty clay infilling c) MFT 6 arrow moldic void and d) MFT 6 vesicle voids. Left column: PPL, right column: XPL.

Figure 9. Photomicrograph of MFT 6: detail of a void of plant component (moldic void). Detail of the previous image: articulated phytolith inside the void. PPL.

Figure 10. Photomicrograph on the uppermost of MFT6: detail of a small bone and a charcoal fragment. PPL.

Figure 11. XRD analysis of the floor. The main component is calcite but also quartz, dolomite, muscovite/clinochlore and feldspars (microcline and albite).

Figure 12. Photomicrographs of floor layer preparation MFTs. a - b) MFT 1 (detrital and more porosity groundmass). c- d) MFT 5 and e - f) MFT 3 (with heterogeneous clayey reddish groundmass). Left column: PPL, right column: XPL.

Figure 13. Photomicrographs of prismatic-type calcitic pseudomorphs (SU 302). Left: general view of the crack and the accumulation; right: detail of these calcite pseudomorphs. PPL.

Figure 14. Photomicrographs of bench MFT7: clay groundmass can be observed together with infilling of micritical carbonation typical of the rock (transit between the Bundsandstein facies and Muschelkalk). PPL and XPL.

Figure 15. Photomicrographs of the geological materials ESEM and microanalysis (red box). a. Sample A and b. Sample B. 
Figure 16. Photomicrographs of the Floor MFT6 (a) it can be observed that its composition is similar to sample A and sample B (2), (See Fig. 15). Floor layer preparation MFT3 (b) in this case its composition is similar to sample B (1), (See Fig. 15). ESEM and microanalysis (red box).

\section{TABLES}

\begin{tabular}{|c|c|c|}
\hline $\begin{array}{c}\text { Profile 1 } \\
\text { (M1 and M2) }\end{array}$ & Sedimentary field description from bottom to top & $\begin{array}{c}\text { Archaeological } \\
\text { sequence }\end{array}$ \\
\hline SU 333 (M1) & $\begin{array}{l}\text { Floor layer preparation: } 10 \mathrm{~cm} \text { thick } \\
\text { Pale brown (10YR } 6 / 3) \\
\text { Silty sands with some subrounded gravels mainly of } \\
\text { limestone } \\
\text { Sharp smooth boundary }\end{array}$ & Phase 1 \\
\hline SU 317 (M1) & $\begin{array}{l}\text { Floor: } 3 \mathrm{~cm} \text { thick } \\
\text { Pale yellow }(2.5 \mathrm{Y} 8 / 2) \\
\text { Silty clayey fine sands } \\
\text { Massive and coherent structure (semi-cemented) } \\
\text { Sharp boundary }\end{array}$ & Phase 1 \\
\hline $\begin{array}{c}\text { SU } 316 \\
\text { (M1 and M2) }\end{array}$ & $\begin{array}{l}\text { Floor layer preparation: } 24 \mathrm{~cm} \text { thick } \\
\text { Red (10R 6/4 10R) - light red (2.5YR 5/4-4/4) } \\
\text { Silty clays with sands and some gravels } \\
\text { Granular structure and it is less coherent } \\
\text { Sharp smooth boundary }\end{array}$ & Phase 2 \\
\hline $\begin{array}{c}\text { SU 296/309 } \\
\text { (M2) }\end{array}$ & $\begin{array}{l}\text { Floor: } 3 \mathrm{~cm} \text { thick } \\
\text { Pale yellow }(2.5 \mathrm{Y} 8 / 2) \\
\text { Silty clayey fine sands } \\
\text { Massive and coherent structure (semi-cemented) } \\
\text { Diffuse smooth boundary }\end{array}$ & Phase 2 \\
\hline \multicolumn{3}{|l|}{ Profile 2 (M3) } \\
\hline SU 287 (M3) & $\begin{array}{l}\text { Floor layer preparation: } 21 \mathrm{~cm} \text { thick } \\
\text { Red (10R 6/4) - light red (2.5YR 5/4-4/4) } \\
\text { Silty sands with subrounded gravels (heterogenic mass) } \\
\text { Granular structure } \\
\text { Sharp smooth boundary }\end{array}$ & Phase 3 \\
\hline SU 278 (M3) & $\begin{array}{l}\text { Floor: } 8-9 \mathrm{~cm} \text { thick } \\
\text { Pale yellow }(2.5 \mathrm{Y} 8 / 2) \\
\text { Silty clayey medium to fine sands } \\
\text { Platy and coherent structure (semi-cemented) } \\
\text { Sharp boundary }\end{array}$ & Phase 3 \\
\hline SU 263 (M3) & $\begin{array}{l}\text { Bench: } 16 \mathrm{~cm} \text { thick } \\
\text { Red (10R 6/4) - light red (2.5YR 5/4-4/4) } \\
\text { Silty clays } \\
\text { Granular structure }\end{array}$ & Phase 3 \\
\hline
\end{tabular}

Table I. Sedimentary field descriptions of the profiles. 
Table II. Micromorphological descriptions of MFT.

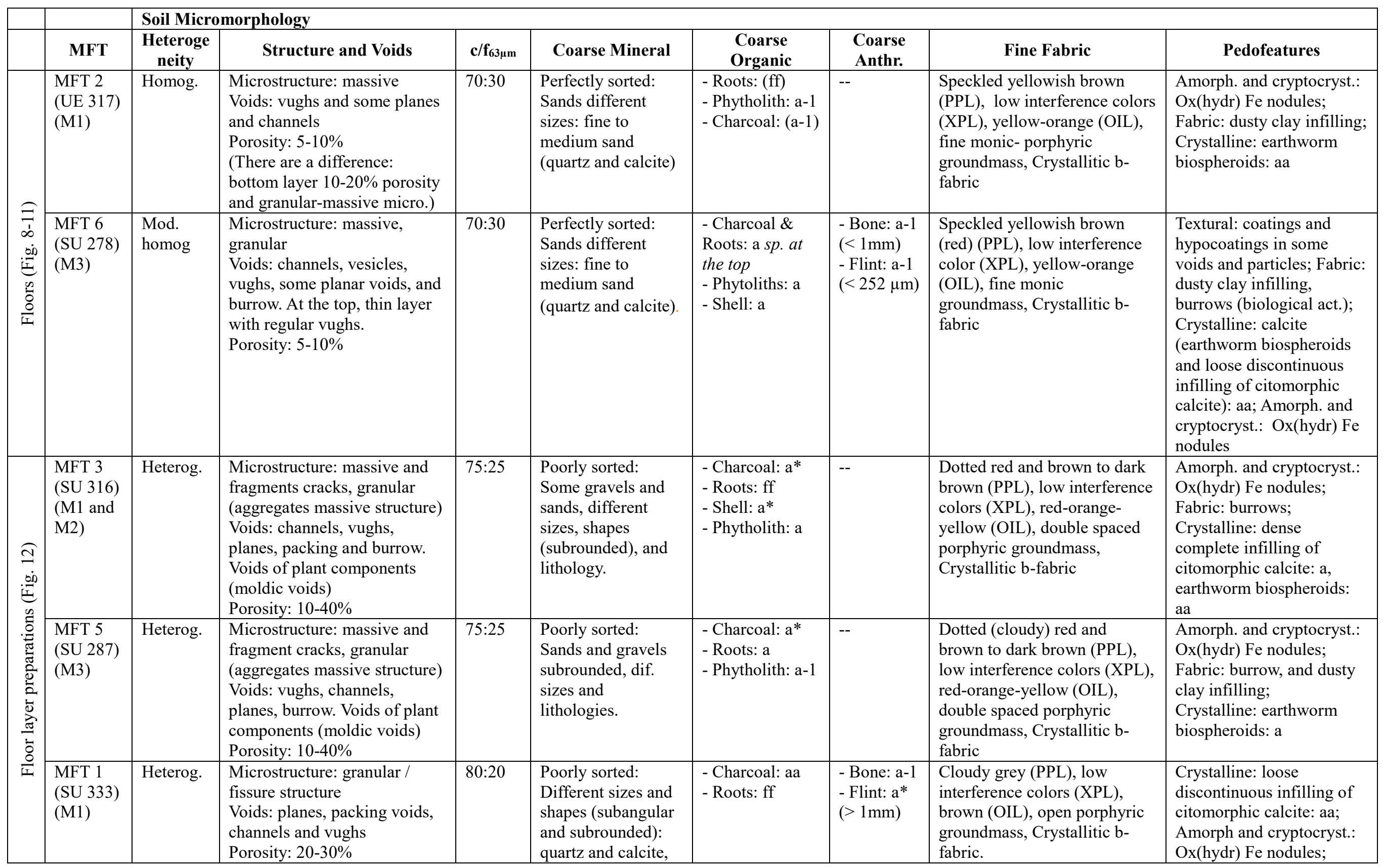




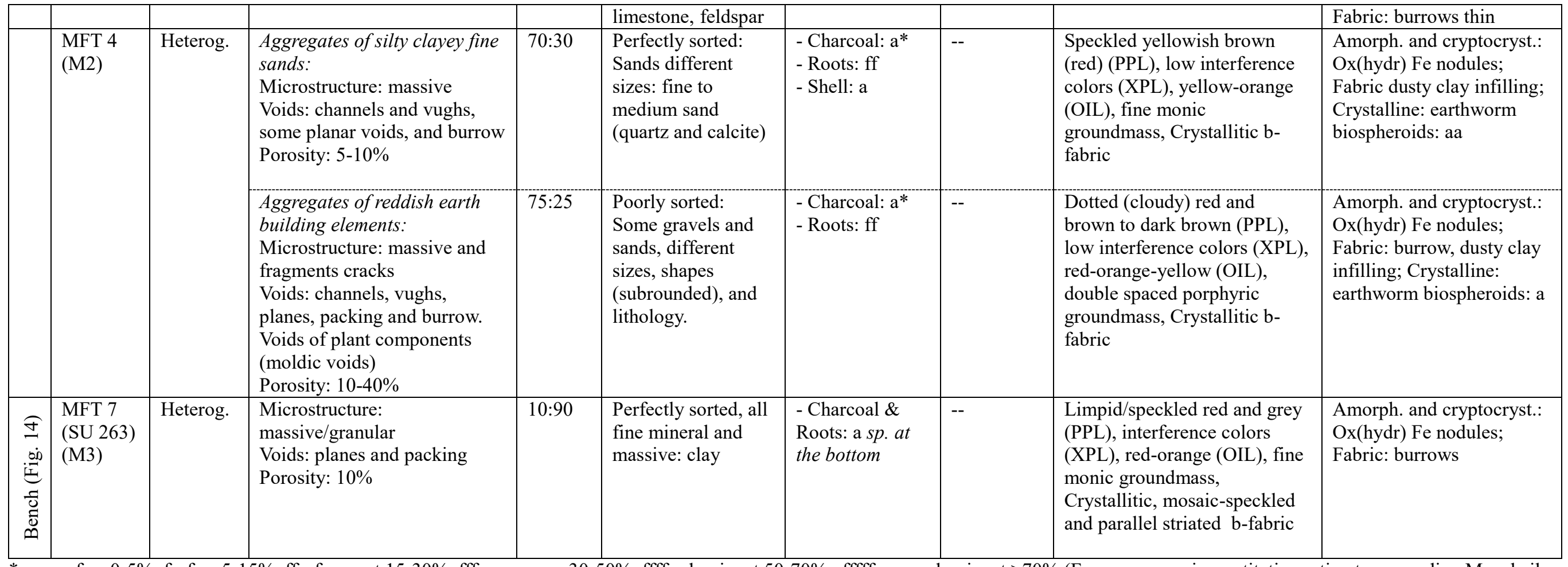

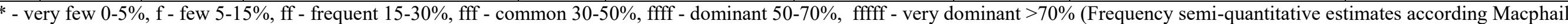
and Goldberg, 2018: 93)

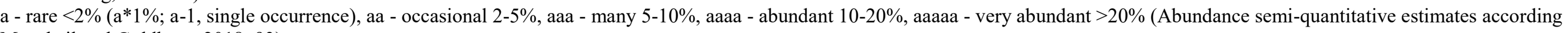
Macphail and Goldberg, 2018: 93) 


\section{FIGURES}
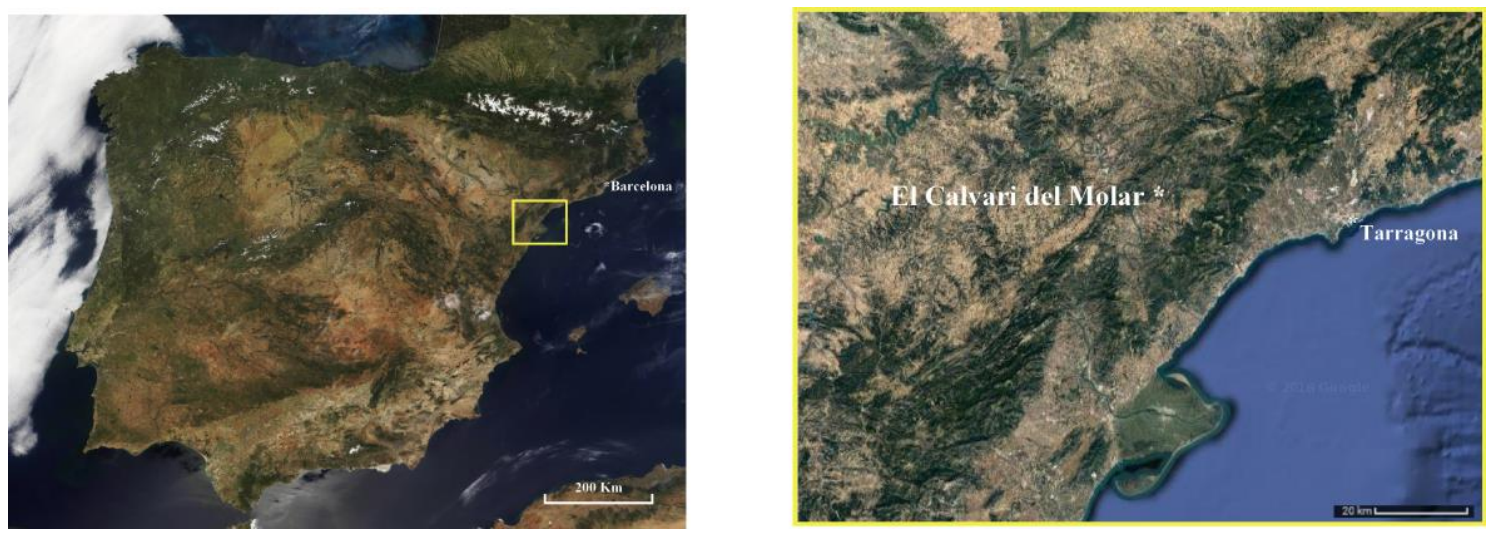

Figure 1. Location of El Calvari del Molar (Tarragona) in the NE Iberia.

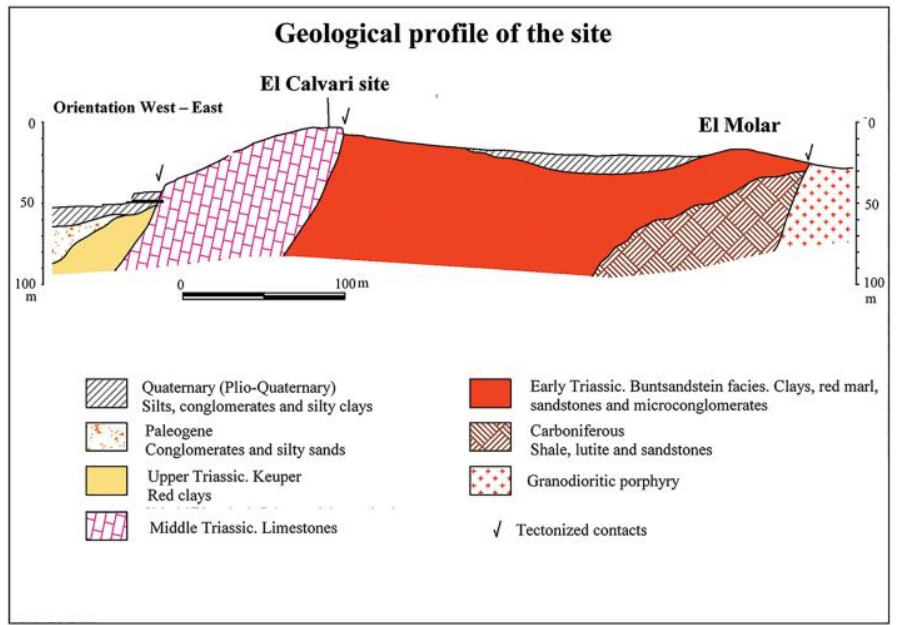

Figure 2. Geological location (Carulla, 2008, modified). 


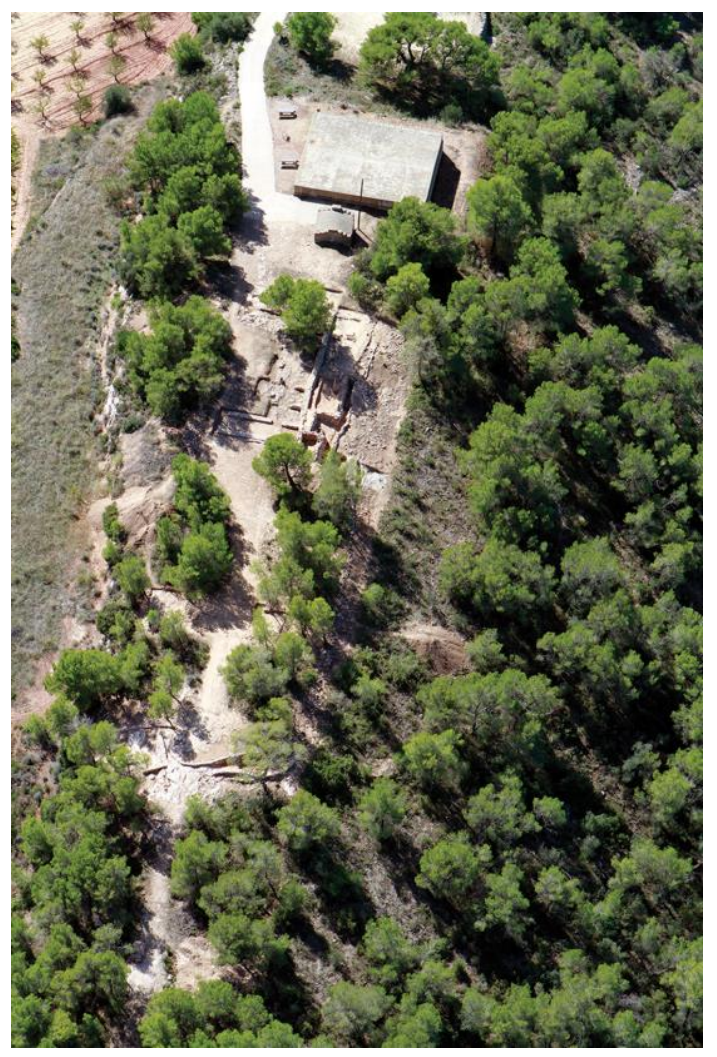

Figure 3. Aerial view of El Calvari del Molar.

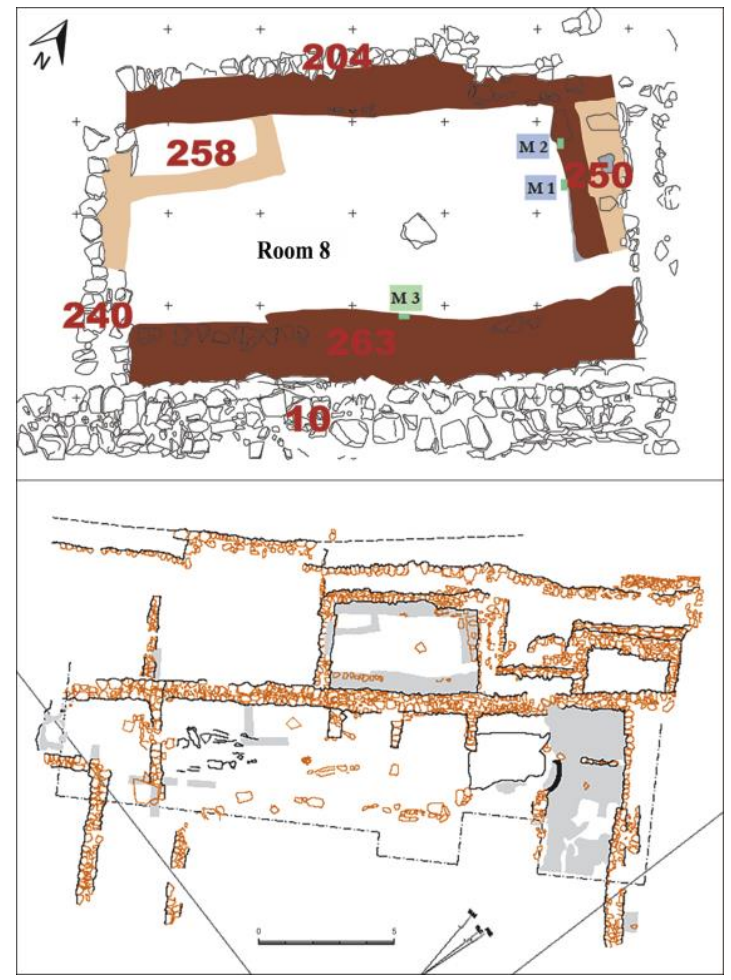

Figure 4. Plan of the archaeological site and detail of the Room 8 with the location of samples (M1, M2 and M3). 

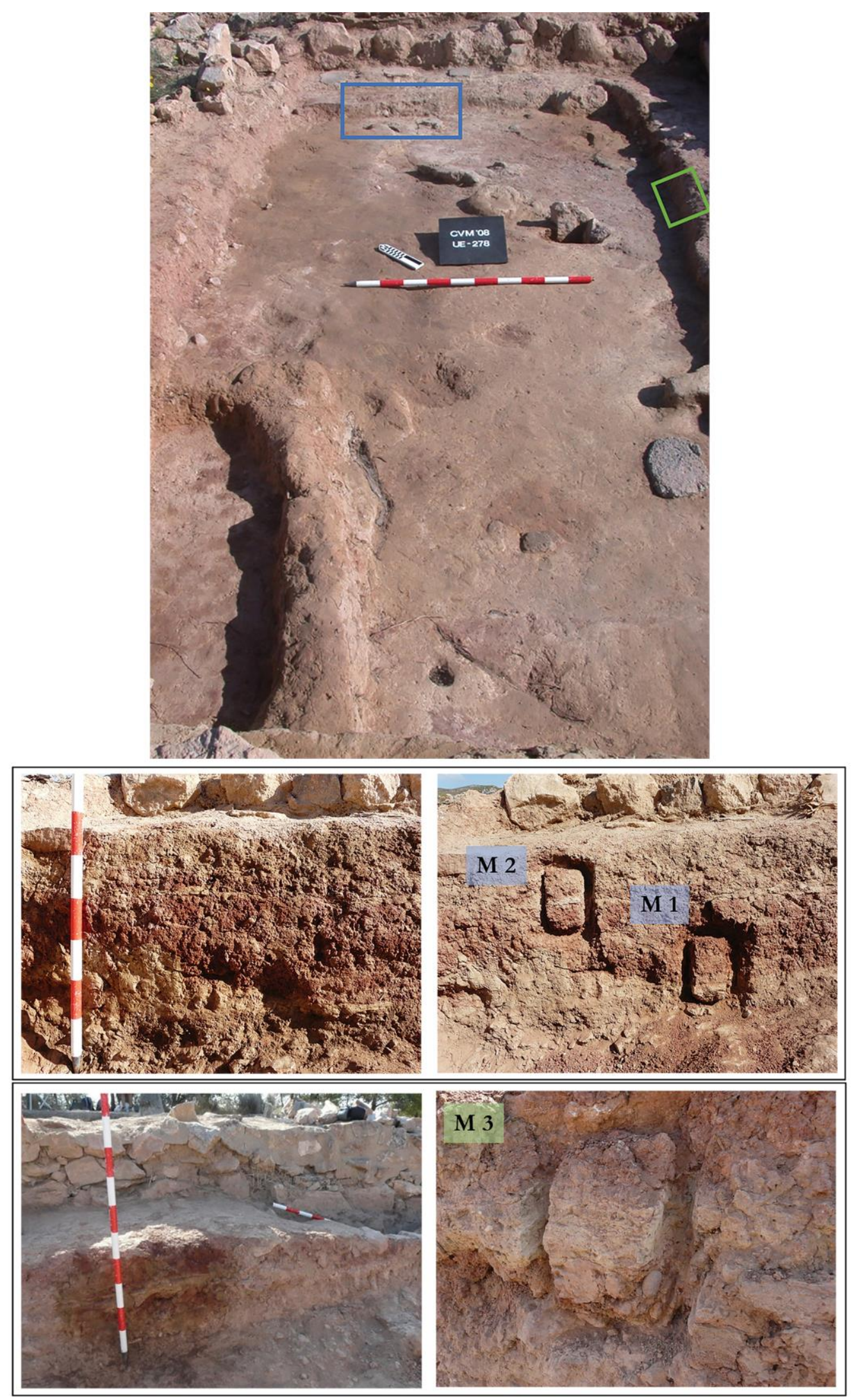

Figure 5. Aerial view of room 8 with the two profiles (Blue: profile 1; Green: profile 2). Front photographs of the two profiles with the process of sampling (Above: profile 1 M1 and M2; Down: profile 2 - M3). 


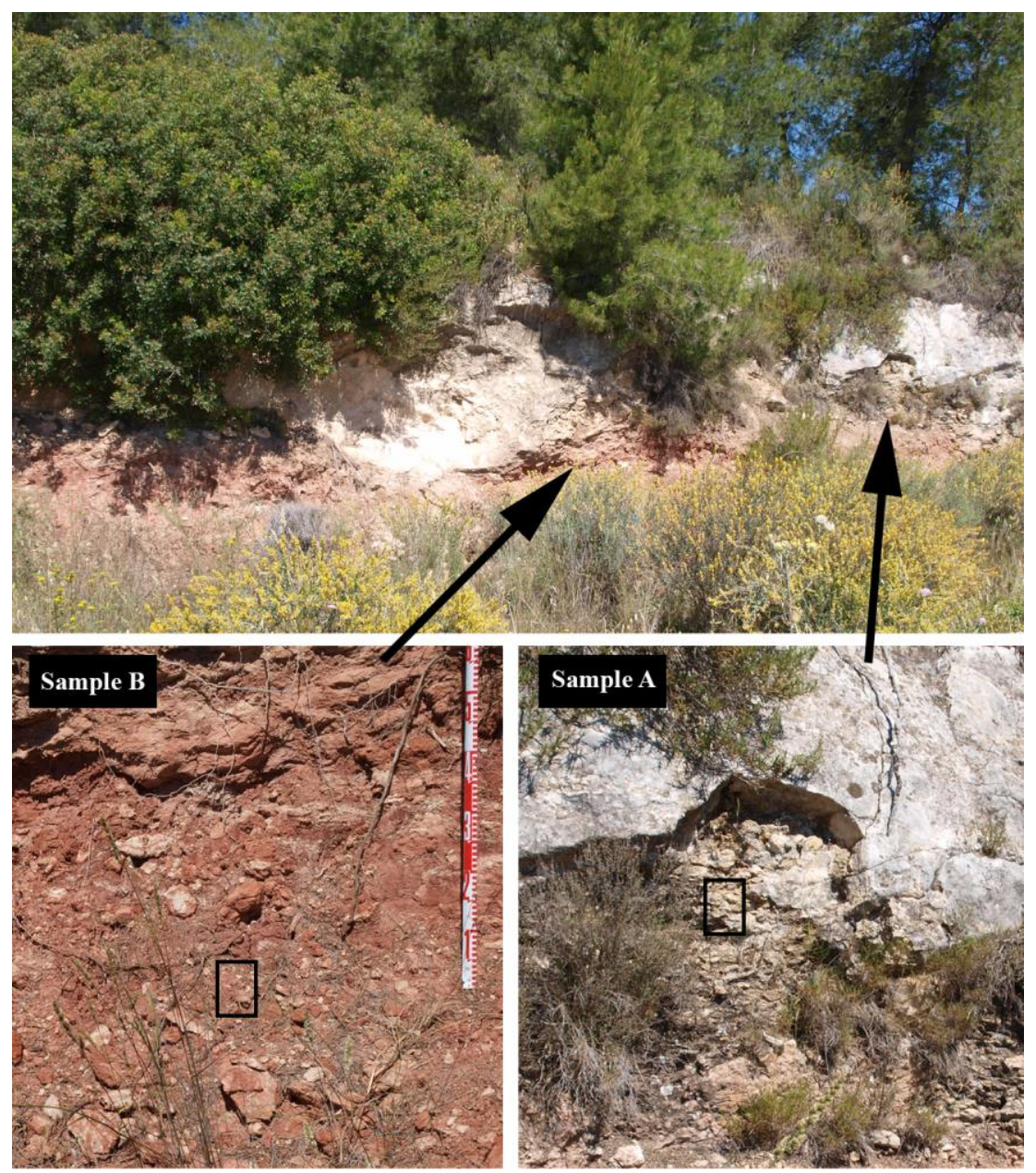

Figure 6. Photograph of the two geological formations around the site: location Muschelkalk (Sample A) and the transition to the Bundsandstein (Sample B). 

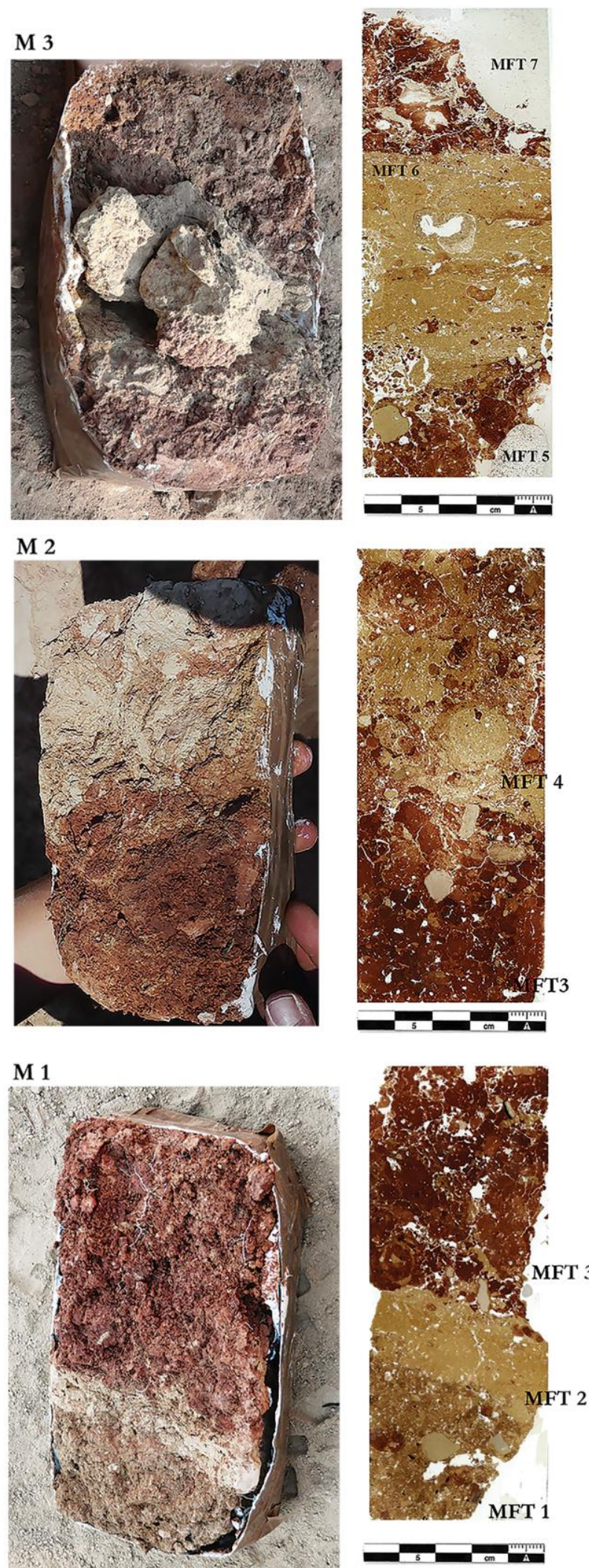

Figure 7. Photographs of the three samples before making their thin sections accompanied by indication of the different MFTs identified. Cronostratigraphic order of the site. 

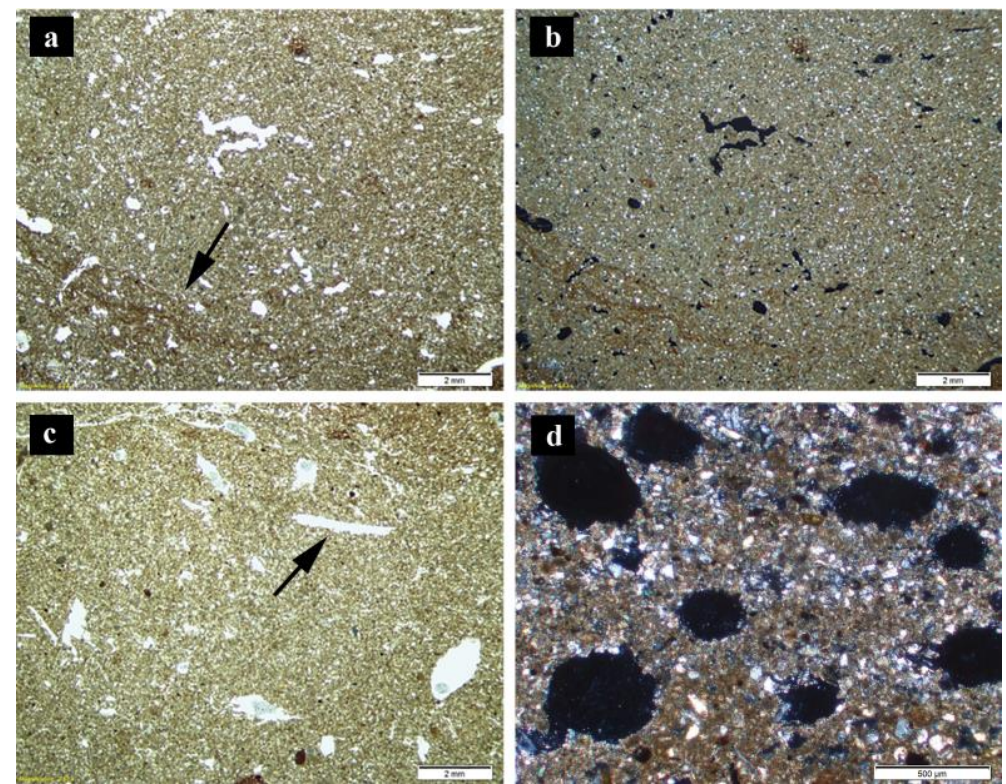

Figure 8. Photomicrographs of the floors MFTs (with silty clayey fine sands groundmass). a - b) MFT 2 arrow dusty clay infilling c) MFT 6 arrow moldic void and d) MFT 6 vesicle voids. Left column: PPL, right column: XPL.

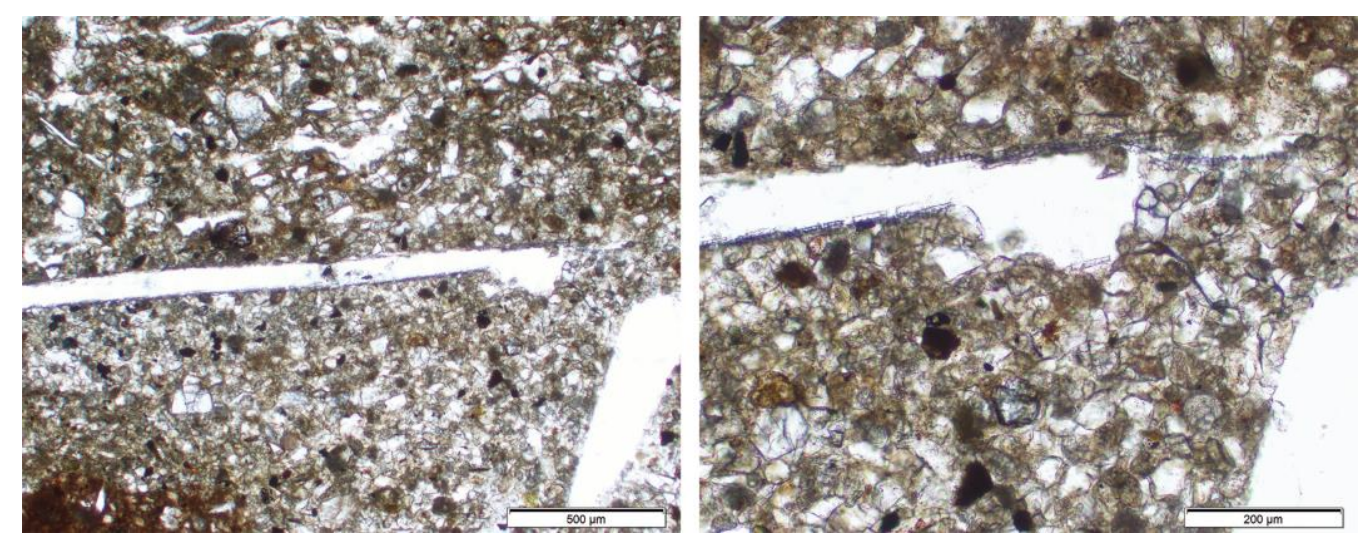

Figure 9. Photomicrograph of MFT 6: detail of a void of plant component (moldic void). Detail of the previous image: articulated phytolith inside the void. PPL. 

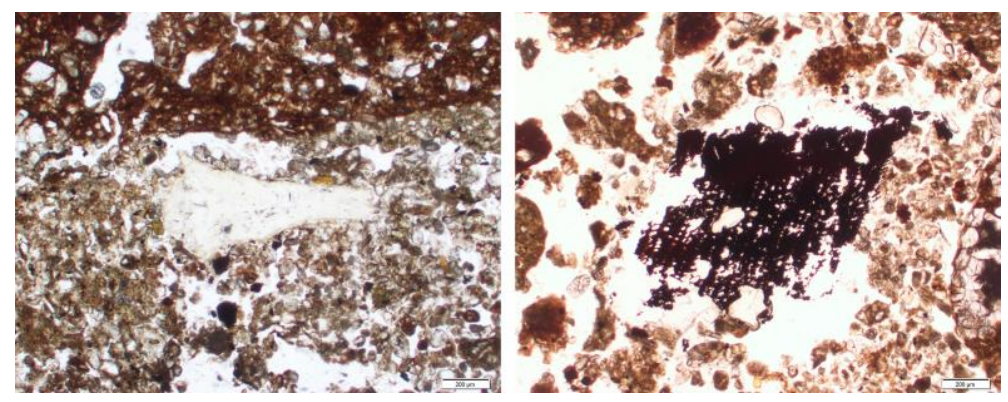

Figure 10. Photomicrograph on the uppermost of MFT6: detail of a small bone and a charcoal fragment. PPL.

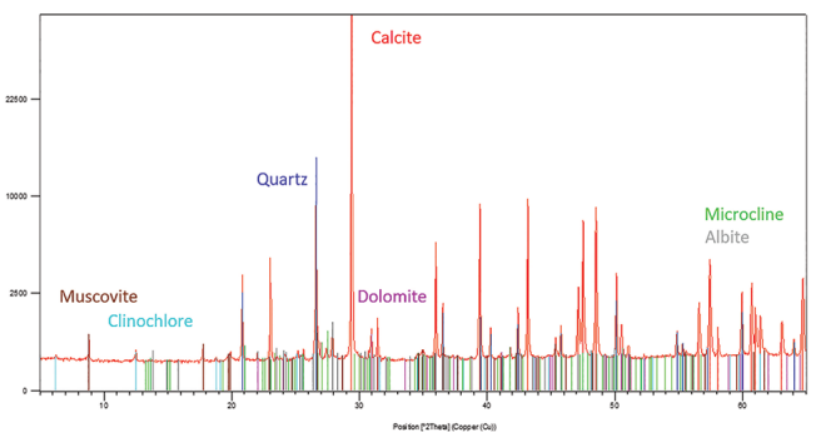

Figure 11. XRD analysis of the floor. The main component is calcite but also quartz, dolomite, muscovite/clinochlore and feldspars (microcline and albite). 

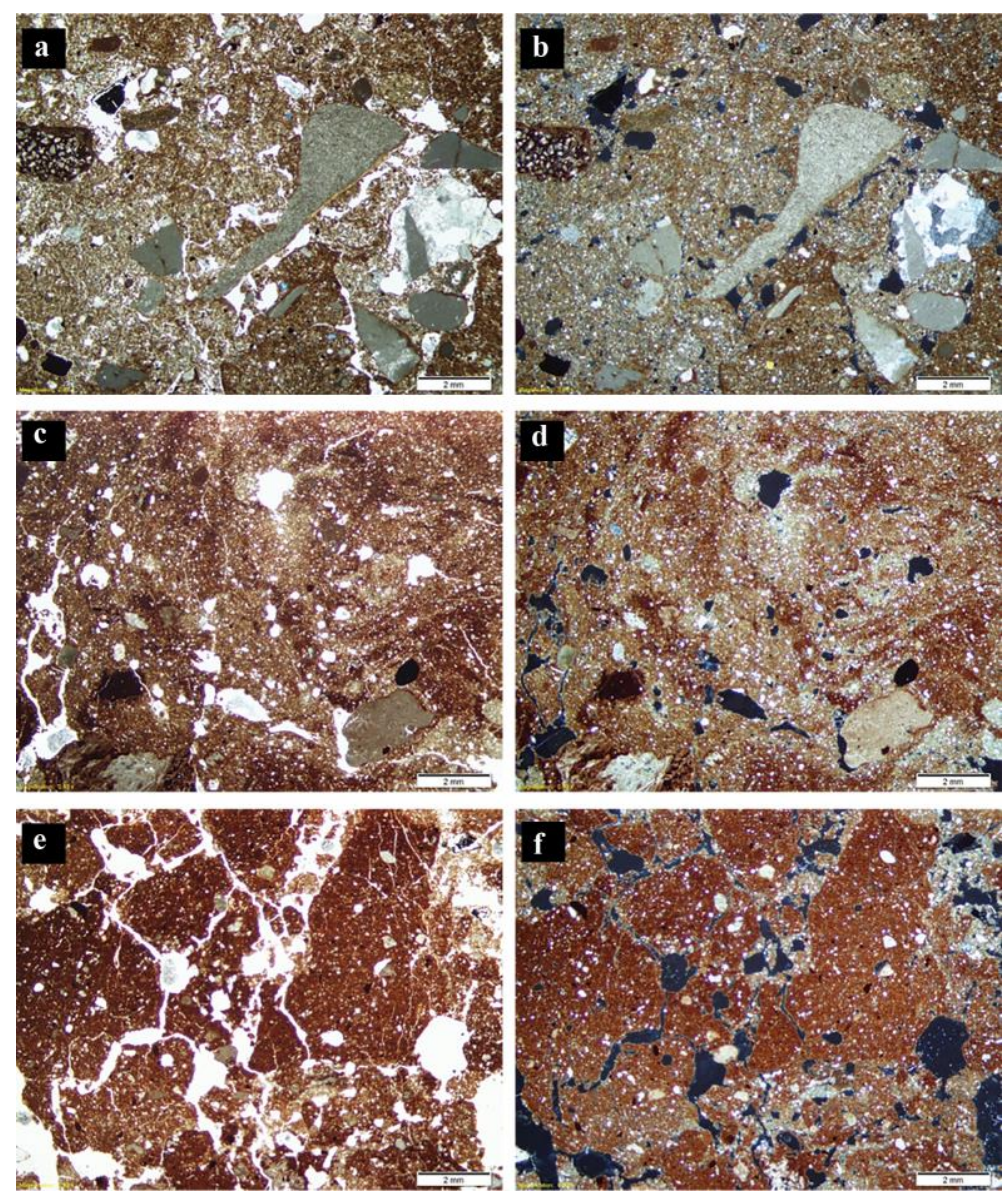

Figure 12. Photomicrographs of floor layer preparation MFTs. a - b) MFT 1 (detrital and more porosity groundmass). c- d) MFT 5 and e - f) MFT 3 (with heterogeneous clayey reddish groundmass). Left column: PPL, right column: XPL.
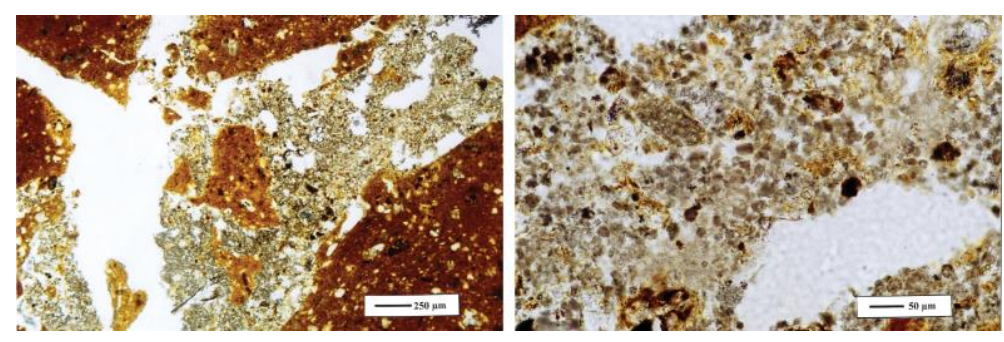

Figure 13. Photomicrographs of prismatic-type calcitic pseudomorphs (SU 302). Left: general view of the crack and the accumulation; right: detail of these calcite pseudomorphs. PPL. 

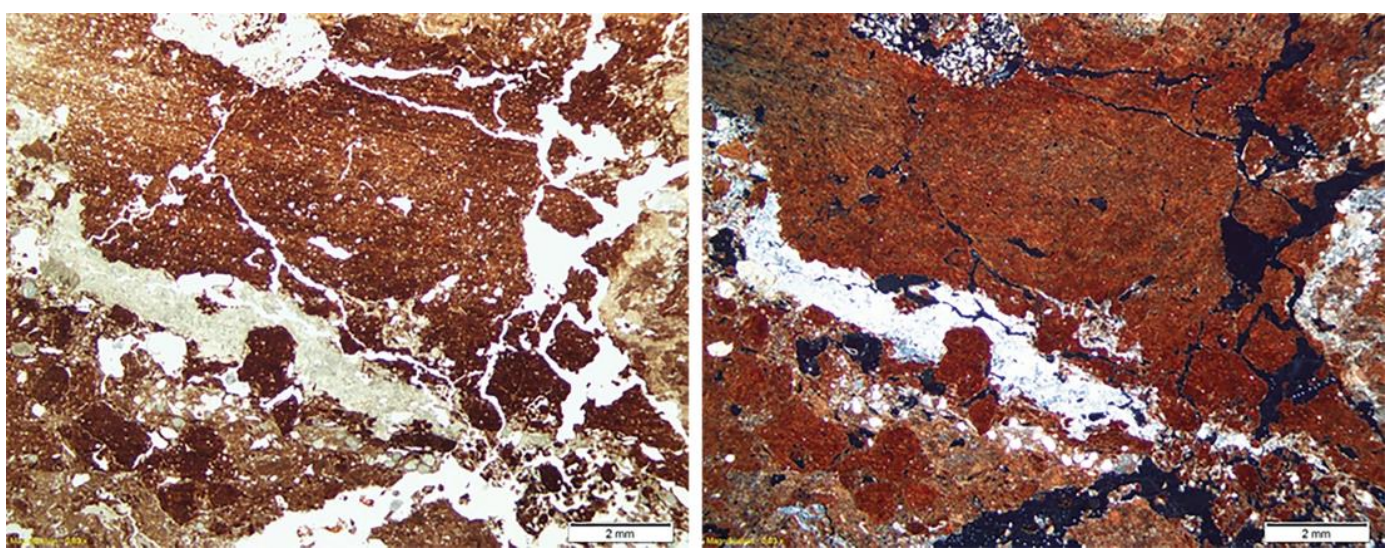

Figure 14. Photomicrographs of bench MFT7: clay groundmass can be observed together with infilling of micritical carbonation typical of the rock (transit between the Bundsandstein facies and Muschelkalk). PPL and XPL. 


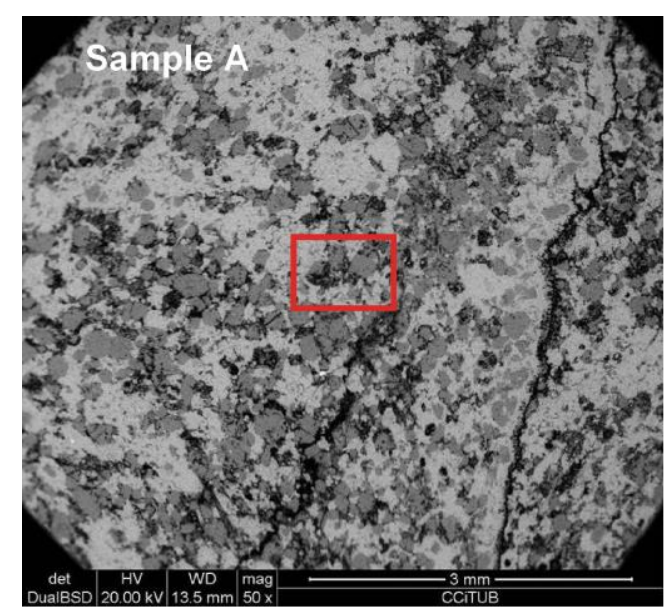

a
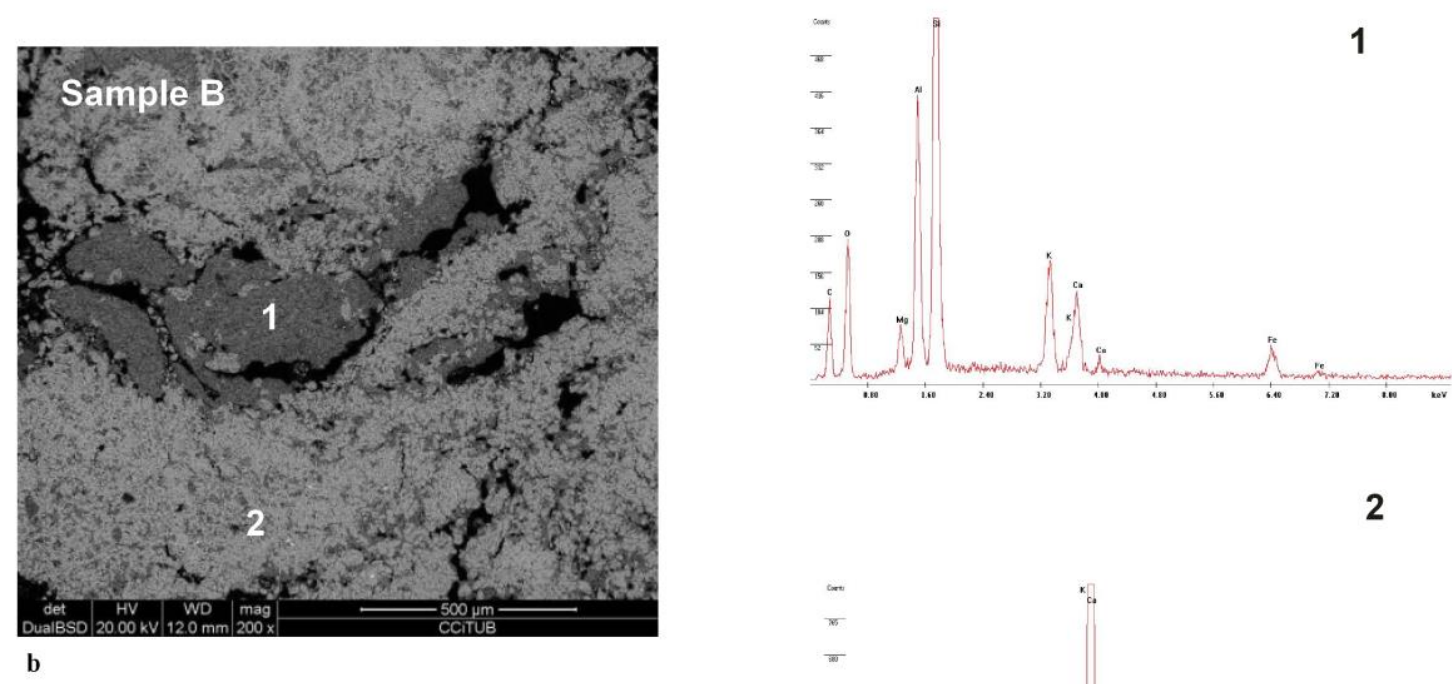

2

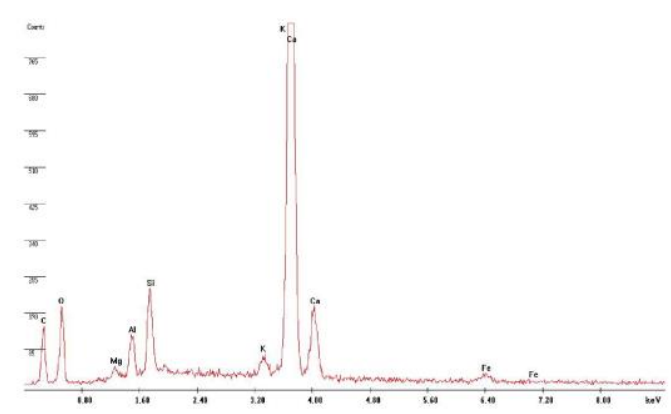

Figure 15. Photomicrographs of the geological materials ESEM and microanalysis (red box). a. Sample A and b. Sample B. 


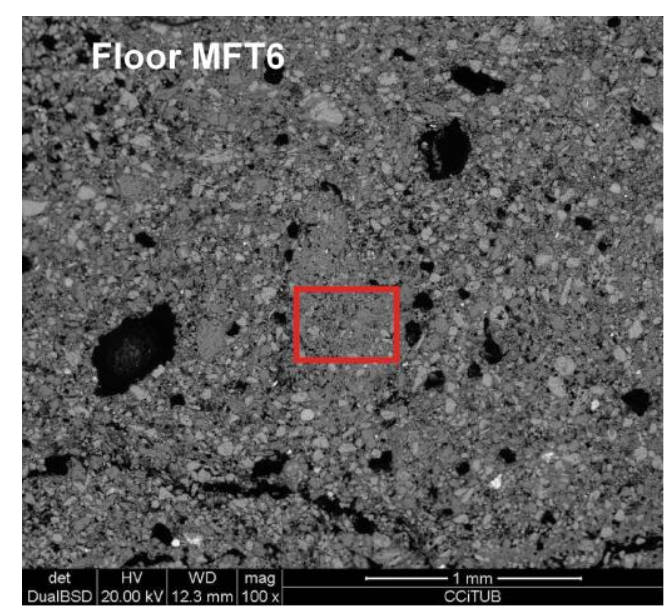

a
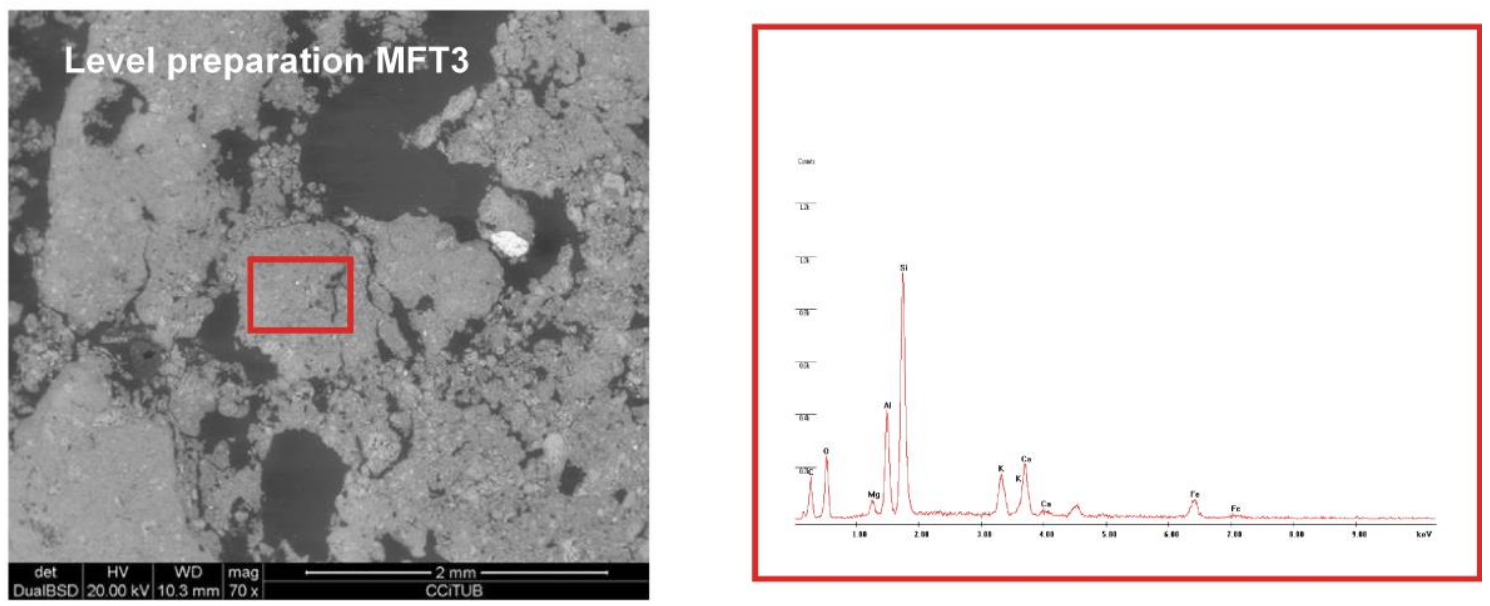

b

Figure 16. Photomicrographs of the Floor MFT6 (a) it can be observed that its composition is similar to sample A and sample B (2), (See Fig. 15). Floor layer preparation MFT3 (b) in this case its composition is similar to sample B (1), (See Fig. 15). ESEM and microanalysis (red box). 